Revista de Estudios Histórico-Jurídicos

[Sección historia del derecho chileno]

XLIII (Valparaíso, Chile, 2021)

[pp. 587-610]

\title{
El SURGIMIENTO DEL GUARDIÁN ADMINISTRATIVO: LA Contraloría General de la República ENTRE 1927 Y 1943
}

[The emergence of the administrative guardian: The Comptroller-General between 1927 and 1943]

\author{
Guillermo JiMÉNEZ*
}

Universidad Adolfo Ibáñez, Chile

\begin{abstract}
RESUMEN
Este artículo examina la creación de la Contraloría General de la República en 1927 y los primeros años de su funcionamiento. Se argumenta que el origen de la Contraloría General en Chile debe entenderse en el contexto de la concentración de poder en el Poder Ejecutivo y del incipiente desarrollo de una burocracia pública moderna tras la dictación de la Constitución de 1925. En sus primeros años la Contraloría General fue un crucial instrumento modernizador de la burocracia. En este período progresivamente la institución fue desarrollando una cultura burocrática propia y se fueron perfilando sus características institucionales actuales. Así, este trabajo examina cómo, a través de varias reformas, la Contraloría General adquirió relativa independencia, y cómo la toma de razón y la potestad dictaminante se formaron con sus rasgos actuales. El período en estudio culmina en 1943 cuando una reforma constitucional la incluyó en la Constitución e inició un proceso de
\end{abstract} AвsтRACт
This article examines the establish-
ment of the Comptroller-General Office in
1927, and the first years of its operation. It is
argued that the origin of the Comptroller-
General Office is better understood in the
context of the concentration of power in
the executive branch and the embryonic de-
velopment of a modern public bureaucracy
after the enactment of the 1925 Constitu-
tion. At the outset the Comptroller-General
Office was a crucial instrument for the
modernization of the public bureaucracy.
In this period the institution gradually
was developing its own bureaucratic cul-
ture and its current institutional features
were taking form. This paper examines
how, through a series of reforms, the
Comptroller-General Office was granted
with a degree of independence, and how
its legality review and its interpretative
powers acquired its current features. The
period under examination ends in 1943
when a constitutional reform entrenched
the Comptroller-General in the Constitu-

* Profesor de Derecho Público, Universidad Adolfo Ibáñez, Facultad de Derecho, Padre Hurtado 750, Viña del Mar, Valparaíso. guillermo.jimenez@uai.cl.0000-0002-7275-8078 
transformación crítico para la Contraloría General de la República.

\section{Palabras clave}

Contraloría - Toma de Razón - Potestad dictaminante - Constitución de 1925 - Ibáñez. tion and triggered a critical transformative process for the office.

KEY Words
Comptroller-General Office - Legal-
ity review - Interpretative power - 1925
Constitution - Ibáñez.

RECIBIDO el 30 de abril de 2020 y ACEPTADO el 21 de enero de 2021

\section{INTRODUCCIÓN}

Este trabajo examina el surgimiento de la Contraloría General de la República a inicios del siglo XX, enfatizando su origen y desarrollo en paralelo con el crecimiento del moderno estado administrativo en Chile ${ }^{1}$. Esta institución surgió como un subproducto del desarrollo de formas de gobierno modernas, centradas en el ejecutivo. En sus inicios la Contraloría General fue un importante instrumento modernizador de una burocracia administrativa que era percibida como disfuncional para satisfacer las necesidades de una sociedad moderna.

En sus orígenes la organización fue concebida como un agente del presidente de la República con la vista puesta en una modernización a larga escala de la burocracia chilena. Durante este periodo la Contraloría General puede ser caracterizada como un instrumento para hacer más efectivo y eficiente el control presidencial sobre la burocracia. Sin embargo, paulatinamente ella fue desarrollando una autonomía burocrática respecto del presidente de la República, esto es, relativa autonomía respecto de la actividad política y partidista ${ }^{2}$. Para ello fue importante un contexto político e institucional que promoviera una concepción tecnocrática de la política y del gobierno, el cultivo de una cultura tecnocrática dentro de la institución, y que se formaran ciertas características institucionales que le permitieran tener un mayor grado de independencia respecto de otros órganos estatales.

Este trabajo se divide en tres secciones principales. La sección I examina dos elementos que constituyen el contexto en que fue creada la Contraloría General de la República. En primer lugar, se destaca la conexión del origen de la institución con la dictación de la Constitución de 1925, que concentró poder político en el Poder Ejecutivo, pero que dejó un vacío en términos de su control jurídico. Como segundo elemento de contexto, esta sección discute el lugar de la Contraloría General en el marco de un programa más amplio de reformas institucionales que propuso un equipo de consultores estadounidenses que asesoraron a un puñado de países latinoamericanos en la década de 1920, esto es, la Misión Kemmerer.

\footnotetext{
${ }^{1}$ Una sugerencia similar, pero sin un análisis detallado, se puede encontrar en JOCELYNHolt, Alfredo, La Contraloría General de la República: su sentido histórico, en Estudios Públicos, 137 (2015), pp. 137-144.

${ }^{2}$ López, Elvira, El proceso de formación de la burocracia estatal chilena, 1810-1930, en RENGIFO, Francisca (ed.), Historia política de Chile, 1810-2010 (Santiago, Fondo de Cultura Económica, 2017), II, pp. 78-82.
} 
Estas reformas tenían por propósito modernizar y racionalizar las prácticas burocráticas de gobierno, lo que da otra clave interpretativa respecto del origen de la Contraloría General de la República. Luego, en la sección II, se bosqueja la importancia del legado del primer contralor general, Pablo Ramírez. Un actor clave en la temprana modernización estatal chilena, Ramírez jugó un rol crítico en la puesta en marcha de la institución. Se sugerirá que las ideas tecnocráticas y autoritarias de esta figura política influyeron en la cultura de la institución. Finalmente, la sección III cierra con un breve análisis del proceso de formación de las características distintivas de la moderna Contraloría General, esto es, su independencia, la toma de razón, y la potestad dictaminante. Se mostrará cómo las principales características de la institución fueron apareciendo de forma paulatina, situándola en una posición distintiva entre el Poder Ejecutivo y el Congreso Nacional. El periodo examinado termina justo antes de la reforma constitucional de 1943 que constitucionalizó a la Contraloría General como un elemento de contrapeso de un Poder Ejecutivo en permanente expansión. Es precisamente el período que se abre a partir de ese evento -que escapa los alcances de este trabajo- lo que exige buscar entender con precisión las dos primeras décadas de la Contraloría General de la República.

\section{El contexto político de la creación de la Contraloría General DE LA REPÚBLICA}

\section{La Constitución de 1925 y el vacio de control}

Para entender los orígenes de la Contraloría General de la República es necesario examinar brevemente el trasfondo político de su fundación. La institución fue creada en el contexto de la transformación del régimen político chileno desde prácticas semi-parlamentarias a un gobierno fuertemente presidencialista. El principal instrumento para poner en práctica estos nuevos arreglos institucionales fue la Constitución de 1925. Dos características de esta Constitución son particularmente importantes para entender el rol que tendrá posteriormente la Contraloría General: la concentración de poder en el Poder Ejecutivo y la ausencia de mecanismos adecuados contra el abuso de poder administrativo.

El principal motor tras la institucionalidad de la Constitución de 1925 fue la concentración de poder en el Poder Ejecutivo y, como consecuencia, el fortalecimiento de la burocracia ${ }^{3}$. De hecho, la Constitución de 1925 fue una reacción a una crisis política y económica que gatilló una inestabilidad institucional profunda a inicios de la década de 1920. En ese entonces, la opinión pública tendía a considerar la relación entre el presidente y el Congreso como desbalanceada y reflejando una forma irregular de parlamentarismo. Como ha dicho un comentarista, "la crisis y el quiebre final del estado oligárquico a inicios de la década de 1920 había producido un profundo sentimiento de descontento entre los chilenos acerca del sistema parlamentario, los políticos, y la así llamada fronda aristocrática. El parlamentarismo estaba moral, intelectual y políticamente com-

${ }^{3}$ Estévez, Carlos, Reformas que la Constitución de 1925 introdujo a la de 1833 (Santiago, Universidad de Chile, 1942), p. 4. 
pletamente desacreditado, de acuerdo a la mayoría de los testimonios"4. Además, este disfuncional proceso político estaba dañando la capacidad de una ya débil administración pública para prestar servicios que una nueva población urbana estaba demandando urgentemente. Correctamente o no, observadores percibían que las oficinas del Poder Ejecutivo estaban completamente "desquiciadas" . Bajo la influencia de la política partidista y el permanente entrometimiento del Congreso, los ministros no tenían la autoridad para corregir errores, y carecían de la estabilidad y continuidad necesaria para llevar a cabo efectivamente sus tareas.

En este contexto, la nueva Constitución se propuso restaurar el gobierno presidencial $^{6}$. El Presidente fue confirmado como la cabeza del gobierno y como el jefe último de la administración pública. Cualquier traza de poder parlamentario para intervenir en los nombramientos ministeriales, y cualquier espacio para incursionar en territorio del Ejecutivo, fue removido de la Constitución?

Respecto de los mecanismos de control del Poder Ejecutivo, la regulación del Poder Judicial merece especial atención ${ }^{8}$. A pesar de robustecer a la judicatura, la Constitución de 1925 no le entregó poderes para efectuar escrutinio de la actuación administrativa. De hecho, aunque se le otorgó a la Corte Suprema una estrecha facultad para declarar que un precepto legal era inaplicable en un caso en particular por razones de inconstitucionalidad, en general los tribunales estuvieron confinados solamente a las disputas penales y civiles. En otras palabras, los tribunales estaban excluidos del área más politizada que representan los asuntos contenciosos administrativos. En su lugar, la Constitución estableció que una jurisdicción administrativa exclusiva estaría a cargo de conocer los reclamos en contra de las autoridades políticas y administrativas, conforme al artículo $87^{9}$.

La legislación que implementaría el artículo 87, sin embargo, nunca fue dictada, provocando una situación en la que los tribunales ordinarios sostuvieron que carecían de jurisdicción para resolver disputas entre privados y órganos administrativos. De hecho, de acuerdo a una doctrina bien establecida, los tribunales competentes para conocer de tales disputas de derecho público sólo podrían ser creados por legislación especial. Si bien el Congreso dictó unas pocas leyes estableciendo tribunales especiales responsables de resolver controversias puntuales entre la administración e individuos privados, en general el artículo 87 se convirtió en una cláusula inactiva, causando un enorme vacío de control jurídico en el sistema constitucional chileno que persistió durante la mayor parte del siglo

\footnotetext{
${ }^{4}$ Silva, Patricio, In the Name of Reason: Technocrats and Politics in Chile (Pennsylvania State University Press, 2008), pp. 55-56.

${ }^{5}$ Estévez, Carlos, Reformas, cit. (n. 3), p. 12.

${ }^{6}$ Faúndez, Julio, Democratization, Development, and Legality: Chile, 1831-1973 (New York, Palgrave Macmillan, 2007), pp. 65. ss.

${ }^{7}$ Bernaschina, Mario, Manual de derecho constitucional (Santiago, Editorial Jurídica de Chile, 1951), II, pp. 34, 52-53; Estévez, Carlos, Reformas, cit. (n. 3), p. 13.

${ }^{8}$ Faúndez, Julio, Democratization, cit. (n. 6), cap. 6; Hilbink, Lisa, Judges Beyond Politics in Democracy and Dictatorship: Lessons from Chile (Cambridge University Press, 2007).

${ }^{9}$ Guerra, José Guillermo, La Constitución de 1925 (Santiago, Establecimientos Gráficos Balcells \& Co., 1929), pp. 462-465; SiLva Bascuñán, Alejandro, Tratado de Derecho Constitucional. La Constitución de 1925 (Santiago, Editorial Jurídica de Chile, 1963), III, pp. 423-431.
} 
$\mathrm{XX}^{10}$. Teniendo esto en cuenta, no es para nada sorprendente que en décadas posteriores la Contraloría General de la República asumiera una función como custodio de la legalidad para llenar el vacío de control dejado por la inactividad de la legislatura ${ }^{11}$.

\section{Las reformas financieras de Kemmerer ${ }^{12}$}

La Contraloría General de la República intentó ser un trasplante legal angloamericano en terreno latinoamericano. Aunque es cierto que la ley que creó la institución incorporó "prácticas que se retrotraen al período colonial" 13 , la principal influencia en el diseño inicial de la Contraloría General parece haber venido del Comptroller-Auditor General británico y su contraparte en los Estados Unidos $^{14}$. De hecho, la oficina fue establecida tras considerar el consejo de una misión de asesores estadounidenses, que recomendaron una variedad de reformas institucionales, incluyendo la creación de una nueva oficina de auditoría que en términos generales seguiría el modelo del Budget and Accounting Act de 1921 que había establecido la General Accounting Office of the United States ${ }^{15}$.

La Misión Kemmerer visitó Chile entre julio y octubre de 1925 en el medio de los debates acerca de la nueva Constitución. Las propuestas de reformas realizadas para el gobierno se dirigieron específicamente tanto al sistema bancario como al financiero. Dado que las propuestas de los economistas estadounidenses recibieron apoyo transversal, no es sorprendente que la mayoría de los proyectos de ley fueron rápidamente aprobados sin cambios relevantes. La ley orgánica de la Contraloría General de la República, sin embargo, fue la más notable excepción. Kemmerer concibió la creación de la Contraloría General desde la perspectiva de la auditoría financiera; la Misión realmente nunca la entendió como una entidad de control jurídico. El propósito explícito que se perseguía con la creación de la institución fue supervigilar la operación de la nueva institucionalidad establecida respecto del proceso presupuestario. Adicionalmente, se esperaba que la

${ }^{10}$ Faúndez, Julio, Democratization, cit. (n. 6), pp. 139 y ss; JunTa de Gobierno (eds.), Los tribunales contenciosos administrativos. Antecedentes para su estudio (Valparaíso, Armada de Chile, 1982); Pantoja, Rolando, La jurisdicción contencioso-administrativa: decisiones legislativas al año 2001 (Santiago, Fundación Facultad de Derecho, 2001); ÉL MISMO. La inexplicable ausencia de una justicia administrativa en el estado de Chile, en Revista de Derecho del Consejo de Defensa del Estado, 13 (2005), pp. 27-69.

${ }^{11}$ FAúndeZ, Julio, Chilean Constitutionalism before Allende: Legality without Courts, en Bulletin of Latin American Research, 29 (2010), p. 34.

${ }^{12}$ En esta sección sigo cercanamente la excelente investigación histórica realizada por Paul Drake. Véase Drake, Paul, The Money Doctor in the Andes: The Kemmerer Missions, 1923-1933 (Duke University Press, 1989).

${ }^{13}$ Drake, Paul, cit. (n. 12), p. 103; Pinto, Sonia; Méndez, Luz María; Vergara, Sergio, Antecedentes históricos de la Contraloría General de la República (Santiago, Contraloría General de la República, 1977).

${ }^{14}$ Correa, Enrique, La Contraloría. El presupuesto del Estado. Su control (Santiago, Talleres Gráficos San Rafael, 1928), pp. 8-20.

${ }^{15}$ Para visiones generales sobre la oficina del contralor de Estados Unidos en esa época, véase Trask, Roger, Defender of the Public Interest: The General Accounting Office, 1921-1966 (US General Accounting Office, 1996); MosHER, Frederick, The GAO: The Quest for Accountability in American Government (Westview Press, 1979), caps. 2 y 3. 
Contraloría General purgara los enmarañados arreglos organizacionales previos en la materia, en los que "varias instituciones descoordinadas, con funciones y competencias traslapadas habían ejercido un control fiscal tardío y aleatorio"16. Dado que la introducción de una única institución poderosa de supervigilancia había sido una política bajo consideración incluso antes de la llegada de Kemmerer, las recomendaciones de la Misión sólo sumaron más fuerza a iniciativas gubernamentales previas ${ }^{17}$. También se esperaba que la Contraloría General generara más información financiera y ésta fuera más confiable. Esto optimizaría el proceso de toma de decisión e implementación gubernamental, particularmente en el ámbito económico. Además, la información producida por la agencia facilitaría el acceso del Estado de Chile a crédito internacional.

La aprobación de la ley de la Contraloría General y luego su puesta en marcha fue un asunto especialmente difícil ${ }^{18}$. De hecho, "la Contraloría, de todos los proyectos de Kemmerer, fue el que tomó más tiempo en hacerse realidad"19. La principal razón de esto pareciera haber sido la desconfianza con que la burocracia tradicional miró a esta nueva organización. Paul Drake indica que "algunos comentaristas y autoridades de gobierno llamaban a un retorno al antiguo sistema de fiscalización" ${ }^{20}$. Anticipando críticas que serían formuladas durante toda la existencia de la institución, "críticos reclamaban que el contralor era demasiado poderoso, complicado y abultado"21. En una comunicación postal con Kemmerer, Walter Van Deusen, un asesor norteamericano que ayudó a adaptar el borrador original al derecho chileno, ilustra apropiadamente los desafíos que enfrentó la iniciativa: "La traducción [del proyecto de Kemmerer] era tan deficiente que algunas partes no podían ser entendidas por nadie. He escuchado que la pobre traducción fue intencional para hacer más difícil la aprobación y la puesta en efecto de la ley, ya que muchos oficiales del gobierno eran muy contrarios a la ley. Hubiera sido imposible haber aprobado la ley en el Congreso. Afortunadamente el actual gobierno necesita limpiar la casa, y ellos pueden aprobar este proyecto bajo la autorización de una ley recientemente dictada por el Congreso que autoriza la consolidación de las oficinas"22.

Fue sólo en febrero de 1927, casi dos años después de la visita de la Misión a Chile, que la primera regulación de la Contraloría General fue promulgada ${ }^{23}$. Esta ley no fue directamente aprobada por el Congreso, sino que fue estable-

${ }^{16}$ DraKe, Paul, cit. (n. 12), p. 103.

${ }^{17}$ Silva Cimma, Enrique, Derecho administrativo chileno y comparado. El servicio público (Santiago, Editorial Jurídica de Chile, 1995), p. 291.

${ }^{18}$ Pinto, Sonia; Méndez, Luz María; Vergara, Sergio, cit. (n. 13); Correa, Enrique, cit. (n. 14).

${ }^{19}$ Drake, Paul, cit. (n. 12), p. 103; Correa, Enrique, cit. (n. 14), p. 18; Jocelyn-Holt, Alfredo, cit. (n. 1), p. 143.

${ }^{20}$ Drake, Paul, cit. (n. 12), p. 104.

${ }^{21}$ Ibíd.

${ }^{22}$ Ibíd., pp. 103-104; Véase también Pinto, Sonia; Méndez, Luz María; Vergara, Sergio, cit. (n. 13), p. 5.

${ }^{23}$ Decreto con fuerza de ley $\mathrm{N}^{\circ} 400 \mathrm{bis}$, de 26 de marzo de 1927, del Ministerio de Hacienda, publicado en el Diario Oficial el 12 de mayo de 1927. 
cida a través de un decreto supremo previa delegación legislativa ${ }^{24}$. El decreto siguió la propuesta de Kemmerer, a pesar de que una comisión encabezada por el superintendente de bancos la adaptó a la legislación nacional ${ }^{25}$. Sin embargo, eran necesarios refinamientos adicionales. Así, bajo el consejo de Kemmerer, el gobierno contrató los servicios del contador público norteamericano Thomas Lill con el mandato de colaborar en la activación práctica de la institución. Su trabajo permitió la dictación de una segunda regulación en diciembre de 1927 que le dio a la organización un marco legal más estable ${ }^{26}$. Finalmente, regulaciones adicionales en 1932 y 1933 entregaron a la oficina la estructura legal que la acompañaría en las siguientes décadas ${ }^{27}$.

La influencia de Kemmerer, sin embargo, no puede oscurecer la importancia de prácticas burocráticas previas que pueden haber tenido un impacto en la resistencia a la reforma e, incluso, en el funcionamiento posterior de la Contraloría General de la República. Varios estudios sobre órganos administrativos chilenos han destacado los elementos de continuidad entre las reformas legales de la década de 1920 y prácticas que se retrotraen a inicios de siglo y incluso a la década de $1880^{28}$. En el caso de la Contraloría General, además, es importante prestar atención a los elementos de continuidad con el Tribunal de Cuentas y la Dirección de Contabilidad, que fueron instituciones que exhibieron notorios rasgos de profesionalismo y burocratización a fines del siglo XIX ${ }^{29}$. De esta forma, ciertamente las propuestas de Kemmerer se combinaron de forma compleja con desarrollos institucionales previos que probablemente facilitaron el fortalecimiento de la Contraloría General en la década siguiente.

En suma, hacia inicios de la década de 1930, los arreglos constitucionales y económicos del país habían cambiado marcadamente, sustentando un nuevo modelo de gobierno dominado por el presidente de la República. El ejecutivo

${ }^{24}$ Sobre el uso de delegaciones de potestad legislativa al presidente de la República en el período 1927-1932, véase el completo estudio de Bronfman, Alan, Génesis de la delegación legislativa en el régimen constitucional de 1925, en Revista de Estudios Histórico-Jurídicos, 40 (2018), pp. 309-340.

${ }^{25}$ Correa, Enrique, cit. (n. 14), p. 18.

${ }^{26}$ Decreto con Fuerza de Ley N $\mathrm{N}^{\text {2 } 2960 b i s, \text { de }} 30$ de diciembre de 1927, del Ministerio de Hacienda, publicado en el Diario Oficial el 19 de enero de 1928.

${ }^{27}$ Decreto ley $\mathrm{N}^{\mathrm{o}} 258$ (publicado en el Diario Oficial el 26 de julio de 1932) y el decreto supremo $\mathrm{N}^{\circ}$ 935, del 20 de marzo de 1933, del Ministerio de Hacienda, publicado en el Diario Oficial el 24 de abril de 1933.

${ }^{28}$ Un ejemplo es el estudio de Juan Carlos Yáñez sobre el surgimiento de política social, que él retrotrae a las décadas previas a 1920, a través de un profundo examen de la Oficina del Trabajo. Véase Yáñez, Juan Carlos, La intervención social en Chile, 1907-1932 (Santiago, Ril Editores, 2008), y YÁÑEZ, Juan Carlos, Antecedentes y evolución histórica de la legislación social en Chile entre 1906 y 1924, en Revista de Estudios Histórico-Jurídicos, 21 (1999), pp. 203-210.

${ }^{29}$ Diego Barría ha estudiado extensamente estas instituciones tanto respecto de su estructura de empleo como los aspectos relativos a la posición social de los funcionarios entre 1880 y 1920. Véase BARría, Diego, Rasgos burocráticos en las reformas administrativas en el Chile de la década de 1880, en Historia Crítica, 56 (2015), p. 70; ÉL MISMO, Carreras administrativas en Chile, 1884-1920 ¿Patronazgo o carreras burocráticas?, en Historia, 51 (2018), pp. 317-338; Él MISMO, An Honourable Profession: Public Employees and Identity Construction in Chile, 1880-1920, en Bulletin of Latin American Research, 38 (2019), pp. 179-191. 
había sido notablemente fortalecido en su interacción con el Congreso, y también poseía herramientas más efectivas para ejercer liderazgo sobre la burocracia. Como veremos, el origen de la Contraloría General reflejó estos nuevos entendimientos constitucionales.

\section{LA CULTURA TECNOCRÁTICA}

La Contraloría General de la República emergió como un sub-producto del crecimiento del moderno Estado desarrollista chileno en las décadas iniciales del siglo $\mathrm{XX}^{30}$. La institución fue establecida bajo la influencia de una cultura política desarrollista y tecnocrática. Este período fue testigo de un genuino momento constitucional no sólo porque coincidió con la dictación de una nueva Constitución, sino también por los cambios institucionales y culturales de largo plazo que estaban teniendo lugar en ese tiempo. Uno de los supuestos fue que el Estado tenía un rol protector que sólo podía ser desempeñado a través de la acción y organización administrativa ${ }^{31}$. Esto implicaba un cambio en la concepción del Estado y de la política. ${ }^{32}$

En el contexto de la nueva Constitución de 1925, no es sorprendente la decisión de otorgar al Poder Ejecutivo - en vez de al Congreso o a la judicatura- amplios poderes de supervisión sobre la burocracia. Un comentarista de la época, por ejemplo, argumentó a favor de establecer un control financiero ex-ante y ex-post sobre la burocracia en la Contraloría General en tanto componente de la rama ejecutiva del gobierno ${ }^{33}$. En su visión, esta rama representaba capacidad, inteligencia, responsabilidad, y continuidad de criterio. De acuerdo con este observador, la rama legislativa, en contraste, encarnaba retraso, incompetencia, e irresponsabilidad. La tarea de la judicatura, a su turno, era resolver disputas entre privados y debería estar confinada a esa tarea. La experticia de los tribunales reside en adjudicar disputas entre intereses privados en conflicto. Los asuntos relativos a los fondos públicos, sin embargo, tenían que ver con el interés público, y esta era un tipo de tarea que sobrepasaba las competencias judiciales ${ }^{34}$.

Esta nueva ideología tecnocrática y pro-ejecutivo está bien ilustrada por la figura del abogado y político chileno Pablo Ramírez ${ }^{35}$. Él encabezó la Contra-

${ }^{30}$ Bernedo, Patricio, La prosperidad económica bajo Carlos Ibáñez del Campo 1927-1929, en Historia, 24 (1985), p. 5.

${ }^{31}$ Góngora, Mario, Ensayo bistórico sobre la noción de estado en Chile en los siglos XIX y XX (Santiago, Editorial Universitaria, 1986), pp. 83, 88; IBÁÑEZ, Adolfo, Los ingenieros, el estado y la política en Chile. Del Ministerio de Fomento a la Corporación de Fomento 1927-1939, en Historia, 18 (1983), pp. 48-49.

${ }^{32}$ YÁÑez, Juan Carlos, La intervención, cit. (n. 28). Véase especialmente la discusión sobre la relación entre política y técnica, y la necesidad de mayor eficacia y centralización a propósito de la creación del Ministerio del Trabajo (pp. 255-256).

${ }^{33}$ Correa, Enrique, cit. (n. 14), pp. 123-125.

${ }^{34}$ Para un sugerente contraste entre la rapidez y seguridad del aparato administrativo, y la lentitud y dilación del sistema judicial, para resolver los problemas sociales de esa época, véase YÁÑEZ, Juan Carlos, La intervención, cit. (n. 28), pp. 275-276.

${ }^{35}$ Para detalles biográficos de Pablo Ramírez, véase SiLva, Patricio, Pablo Ramírez: A Political 
loría General en el momento de su creación en 1927. Incluso más importante, él directamente influyó en los nombramientos de sus sucesores hasta la década de 1950. Los compromisos ideológicos de Ramírez ayudan a entender la cultura institucional de la organización en esta época. Estos compromisos pueden ser resumidos por el proyecto de "construir un estado fuerte y eficiente [mediante el aislamiento] completo de la administración pública de las actividades políticas con el fin de evitar su subordinación a los debates parlamentarios y los intereses partidistas" $"$.

Ramírez estudió derecho en la Universidad de Chile, donde fue discípulo de Valentín Letelier ${ }^{37}$. Tempranamente, se unió al lado más colectivista del Partido Radical. En 1912, Ramírez fue elegido diputado, obteniendo su primer cargo político relevante en el Congreso Nacional. Siendo muy crítico de la burocracia tradicional en el régimen parlamentario, fuertemente promovió reformas administrativas de amplio alcance ${ }^{38}$. En su opinión, el gobierno "carecía de los poderes esenciales para gobernar" ${ }^{\prime 39}$. En 1925, aprovechando su dominio del idioma inglés, comenzó a colaborar con la Misión Kemmerer. El mismo año, comenzó asesorando al ministro del Interior Carlos Ibáñez, quien se convenció de que para implementar las reformas de Kemmerer y la reforma estatal en general era necesario un equipo de tecnócratas jóvenes, profesionales, de clase media, y apolíticos ${ }^{40}$. Con 40 años de edad, Pablo Ramírez fue nombrado ministro de Hacienda, con el mandato de implementar la reorganización financiera y la reforma general de la administración pública. En esta posición, reorganizó numerosos servicios administrativos, introdujo técnicas de gestión privada, implementó nueva legislación financiera, y puso en marcha la Contraloría General ${ }^{41}$. Como puede verse, las medidas de Ramírez hacen eco de la aproximación de "gestión científica" desarrollada en Estados Unidos a fines del siglo XIX y comienzos del siglo XX, que concebía la administración pública como una "forma de gestión análoga a la gestión del sector privado" ${ }^{42}$.

El proyecto más importante de Pablo Ramírez fue ser el cerebro tras la puesta en marcha de la Contraloría General de la República ${ }^{43}$. Su preferencia por personal técnico se refleja en los subsecuentes nombramientos en la institución,

Technocrat Avant-La-Lettre, en Centeno, Miguel y Silva, Patricio (eds.), The Politics of Expertise in Latin America (Basinsgtoke Macmillan, 1998); EsPOnDA, Jaime, Pablo Ramirez: el chileno desconocido (Santiago, Ril Editores, 2013).

${ }^{36}$ Silva, Patricio, Pablo Ramírez, cit. (n. 35), p. 54

${ }^{37}$ Sobre la influencia intelectual de Valentín Letelier en el estudio de la administración pública en la época, véase Barría, Diego, Positivism, Evolutionism, and Public Administration: The Work of Valentin Letelier (1886-1917), en Administrative Theory \& Praxis, 39 (2017), pp. 275-291.

${ }^{38}$ Silva, Patricio, Pablo Ramírez cit. (n. 35), capítulo 2.

${ }^{39}$ EsPONDA, Jaime, cit. (n. 35), p. 73.

${ }^{40}$ Ibíd., pp. 117-118; Silva, Patricio, In the Name cit. (n. 4), p. 73.

${ }^{41}$ Esponda, Jaime, cit. (n. 35), pp. 147-150.

${ }^{42}$ Cane, Peter, Controlling Administrative Power: An Historical Comparison (Cambridge University Press, 2016), p. 451; VILE, MJC, Constitutionalism and the Separation of Powers (2a ed., Indianapolis, Liberty Fund, 1998), cap. 10.

${ }^{43}$ Esponda, Jaime, cit. (n. 35), p. 154. 
mostrando una marcada preferencia por ingenieros sobre "el elemento jurídico que previamente monopolizaba las oficinas [administrativas]" ${ }^{4}$. En el origen de la institución, él ocupó las posiciones conjuntas de contralor general y ministro de Hacienda (entre marzo y julio de 1927). Como ministro, luego recomendó el nombramiento de Kenneth Page, el segundo funcionario en encabezar la institución, y continuó la instalación de la oficina bajo la asesoría de Thomas Lill ${ }^{45}$. Page, quien fue previamente agente en la bolsa de Valparaíso, ocupó el cargo por sólo cinco meses entre julio y diciembre de 1927, pues renunció tras entrar en conflictos con el ministro Ramírez, y volvió al sector privado ${ }^{46}$. En su reemplazo asumió Rodolfo Jaramillo, un joven profesional cercano a Ramírez ${ }^{47}$. Ingeniero especializado en ferrocarriles y con amplia experiencia en el sector público, Jaramillo se mantuvo en el cargo por un año entre 1928 y 1929. Posteriormente, entre enero y noviembre de 1929, la oficina fue liderada por Edecio Torrealba, quien también había estudiado ingeniería, era un miembro del Partido Radical, y ocupó varios cargos directivos en la administración pública ${ }^{48}$. Este funcionario fue sucedido por Miguel Solar, quien había tenido una larga carrera en la burocracia pública antes de unirse a la Contraloría General como jefe superior entre 1929 y $1932^{49}$. Un abogado fue nombrado tras la renuncia de Solar en 1932. Se trató de Gustavo Ibáñez, quien tenía una vasta experiencia en el Ministerio de Hacienda y encabezó la Contraloría por seis años y medio entre 1932 y $1938^{50}$. Así, en sus años iniciales, la Contraloría fue integrada por personal que compartía una mentalidad tecnocrática que contrastaba con la forma de socialización, en general, más legalista de sus contrapartes en la judicatura.

Mientras la crisis económica de 1929 golpeaba al país, Ramírez tuvo que renunciar y fue incluso acusado constitucionalmente en el Congreso Nacional por acoso político en contra de miembros del Consejo de Defensa del Estado, la organización a cargo de representar al Estado ante los tribunales. De ahí en adelante, la influencia de Ramírez sobre la burocracia chilena decayó. Sin embargo, una década más tarde cuando su amigo cercano el abogado Agustín Vigorena fuera nombrado contralor general en 1939, Ramírez retomó su posición de influencia ${ }^{51}$. Posteriormente, en un evento crítico, el contralor Vigorena fue exitosamente destituido mediante una acusación constitucional en 1945, y Pablo Ramírez nuevamente se las arregló para influir en el nombramiento de su sucesor. De hecho, el antiguo juez de corte de apelaciones Humberto Mewes, quien era cuñado de Ramírez y correligionario en el Partido Radical, fue convencido por Ramírez de aceptar el cargo a pesar del hecho de que era más bien inexperto en

${ }^{44}$ Silva, Patricio, In the Name, cit. (n. 4), p. 75.

${ }^{45}$ Esponda, Jaime, cit. (n. 35), p. 187.

${ }^{46}$ Figueroa, Virgilio, Diccionario histórico biográfico y bibliográfico de Chile (Santiago, Balcells \& Co., 1931), IV-V, p. 454.

${ }^{47}$ Ibíd., III, pp. 565-567.

${ }^{48}$ FigueroA, Virgilio, cit. (n. 46), pp. 910-912.

${ }^{49}$ Ibíd., pp. 853-854.

${ }^{50}$ FigueroA, Virgilio, cit. (n. 47), p. 514

${ }^{51}$ Esponda, Jaime, cit. (n. 35), p. 320. 
derecho administrativo ${ }^{52}$. El contralor Mewes permaneció en la jefatura entre febrero de 1946 y junio de 1952, cuando renunció tras ser amenazado con una nueva acusación constitucional por la oposición ${ }^{53}$.

En conclusión, la influencia de la ideología tecnocrática del período puede ser percibida durante los años iniciales de la Contraloría General desde finales de 1920 en adelante. De acuerdo a algunos historiadores, las bases de un sistema de estatismo presidencial fueron sentadas en este período ${ }^{54}$. En otras palabras, se creó una completa estructura administrativa bajo el control inmediato del presidente de la República, concentrando poder en el Poder Ejecutivo. Por lo tanto, la tecnocracia y el autoritarismo parecen estar bien impresos en la cultura institucional de la organización en sus primeros años. Sin embargo, esto también ayudó a la oficina a obtener aceptación y credibilidad a los ojos del Poder Ejecutivo, y es posible afirmar que incluso facilitó una expansión adicional de su influencia en las siguientes décadas.

\section{LA FORMACIÓN DE LOS ELEMENTOS INSTITUCIONALES ESENCIALES}

Tras examinar el contexto del establecimiento de la Contraloría General de la República y las fuerzas institucionales y personales que la movieron en sus años iniciales, ahora es el momento de revisar brevemente la manera en que las regulaciones legales le dieron forma a la institución y sus principales procedimientos. Me enfocaré en tres aspectos: el nombramiento y remoción del jefe superior de la oficina y el resto del personal; el poder de revisión ex-ante a través de la toma de razón; y la potestad dictaminante. Esta sección se enfocará principalmente en las regulaciones dictadas entre 1927 y 1932 ya que ellas establecieron los cimientos jurídicos de la institución ${ }^{55}$. Estos preceptos fueron dictados en tiempos de tumulto y, como era previsible, fueron el resultado de una discrecionalidad presidencial prácticamente ilimitada. Como es de esperar, no hay registros de los debates alrededor de estos cuerpos legales y, adicionalmente, el contexto institucional de su dictación explica un marcado sesgo a favor del Poder Ejecutivo. En línea con los puntos destacados en secciones previas, la imagen que estos materiales reflejan es el de una institución que es concebida como una herramienta de control presidencial de la burocracia que paulatinamente va obteniendo un mayor grado de autonomía.

${ }^{52}$ Esponda, Jaime, cit. (n. 35), p. 340; Silva Cimma, Enrique, Memorias privadas de un hombre público (Santiago, Editorial Andrés Bello, 2000), pp. 147-148.

${ }^{53}$ De Ramón, Armando, Miembros de los Poderes Ejecutivo, Legislativo y Judicial (Santiago, Ediciones Universidad Católica de Chile, 2003), III, p. 130; Silva Cimma, Enrique, Memorias, cit. (n. 52), pp. 191-196.

${ }^{54}$ Bravo, Bernardino, Régimen de gobierno y partidos politicos en Chile 1924-1973 (Santiago, Editorial Jurídica de Chile, 1986), pp. 172-173.

${ }^{55}$ Principalmente son estas tres regulaciones: (i) El DFL N ${ }^{\circ} 400$ bis, de 26 de marzo de 1927, del Ministerio de Hacienda (D.O. 12 de mayo de 1927); (ii) El DFL No 2960bis, de 30 de diciembre de 1927, del Ministerio de Hacienda (D.O. 19 de enero de 1928; y (iii) el DL No 258 (D.O. 26 de julio de 1932). 


\section{Independencia y reclutamiento}

La independencia de la institución, incluyendo su ubicación institucional, nombramiento, mantención en el cargo, y remoción de su jefe superior, han sido aspectos cruciales en el diseño de oficinas de Contralorías Generales en todas partes. La regulación que Chile siguió como modelo -el Budget and Accounting Act de 1921 de Estados Unidos- ha sido descrita como la "culminación de un movimiento para asegurar que los funcionarios de auditoría de la nación fueran independientes del control del ejecutivo" 56 . En el siglo XIX, la independencia fue un aspecto controvertido de la organización del contralor general de Estados Unidos debido a que su especial autoridad cuasi-judicial, requería de un "complejo balance entre el poder presidencial, la prerrogativa del Congreso, y la necesidad de independencia de la agencia" ${ }^{\prime 5}$. En otras palabras, dadas sus funciones de control jurídico, desde sus orígenes esta institución siempre ha tenido alguna forma de relativa independencia del control presidencial ${ }^{58}$. La ley de 1921 también generó controversia al respecto. Durante el debate legislativo hubo serios desacuerdos acerca del grado de independencia otorgado a la oficina y su ubicación institucional. Eventualmente, se aprobaron preceptos que establecieron que el presidente, con el acuerdo y consentimiento del Senado, nombraría el jefe de la institución; también se estableció que habría un período fijo para el contralor general y un procedimiento estricto -que involucrara la intervención del Congreso- para removerlo del cargo ${ }^{59}$.

En contraste, en el modelo original la Contraloría General chilena -contenida en los DFL 400bis, y 2960bis- ésta no fue concebida como una institución independiente. Más bien, ella tenía una posición subordinada al presidente de la República. A este respecto las reglas relativas al nombramiento y remoción del contralor general y su personal resultan instructivas. Estas normas representan el más alto nivel de injerencia presidencial sobre la institución. En un comienzo, el poder para nombrar al contralor residía exclusivamente en el presidente de la República, y las regulaciones explícitamente establecían que éste respondía directamente ante el presidente del debido desempeño de sus funciones ${ }^{60}$. A pesar de eso, haciendo eco de una regla contenida en la sección 301 de la ley orgánica de su contraparte de Estados Unidos, el DFL 400bis disponía que la Contraloría General "será independiente de todos los Ministerios y las demás oficinas del Estado" ". Pero vale la pena notar que esta regla no confería a la institución independencia frente al presidente ${ }^{62}$. Su propósito fue meramente blindarla de influencias de otros

\footnotetext{
${ }^{56}$ Trask, Roger, cit. (n. 15), p. 1.

${ }^{57}$ Mashaw, Jerry, Creating the Administrative Constitution: The Lost One Hundred Years of American Administrative Law (Yale University Press, 2012), pp. 40-42.

${ }^{58}$ Lessig, Lawrence y Sunstein, Cass, The President and the Administration, en Columbia Law Review, 94 (1994), pp. 17-18; Cane, Peter, cit. (n. 42), p. 163.

${ }^{59}$ Trask, Roger, cit. (n. 15), p. 41-42

${ }^{60}$ Véase el artículo 2 del DFL 400bis; y artículo 2 del DFL 2960 bis.

${ }^{61}$ Artículo 1 del decreto con fuerza de ley 400 bis.

${ }^{62}$ Véase artículo 12 a) del decreto supremo No 7912, del Ministerio del Interior, de 1927, que organiza las secretarías de estado, que estipula que el contralor es directamente dependiente del presidente de la República.
} 
órganos administrativos, y asegurar una relación directa, sin mediación, con el presidente. Se pretendía que el estatus de la Contraloría General fuera el de un ministerio, pero protegido en contra de la inestabilidad política ${ }^{63}$.

La influencia presidencial no estaba confinada al jefe superior. Bajo el DFL 400bis, el poder para nombrar, suspender, o remover cualquier funcionario de la oficina fue otorgado al jefe del servicio, quien tenía que rendir cuenta de su ejercicio al presidente de la República (artículo 39). El DFL 2960bis fue incluso más allá al establecer que el contralor general, el subcontralor, y el inspector general serían de nombramiento presidencial. Adicionalmente, se dispuso que el contralor tenía el poder de nombrar el resto del personal "con la aprobación escrita del presidente de la República" (artículo $5^{\circ}$ ). Claramente, este último decreto representó un marco jurídico que implicó un menor reconocimiento de autonomía a la oficina ${ }^{64}$. De hecho, el DL 258 de 1932 retornó a la regulación original, eliminando el requisito de aprobación presidencial por escrito para el reclutamiento de empleados (artículo $3^{\circ}$ ).

El DFL 400bis permaneció en silencio respecto de la remoción del contralor general, implicando en la práctica que el presidente de la República podía removerlo del cargo a su voluntad. Más tarde, evidenciando una cierta influencia estadounidense, el DFL 2960bis estableció que el contralor permanecería en su cargo por seis años, y que podría ser renovado en el cargo (artículo $\left.2^{\circ}\right)^{65}$. Sin embargo, en general, esta autoridad duraba en el cargo mientras contara con la confianza del presidente tal como en los marcos legales previos. El DL 258 de 1932 alteró considerablemente los preceptos sobre mantención y remoción del cargo. Derogó el período fijo de duración del cargo y, además, innovó blindando al contralor con las protecciones concedidas a los magistrados de los tribunales superiores de justicia. De hecho, el DL 258 indicó que "El contralor general y el subcontralor gozarán de las prerrogativas e inamovilidad que las leyes señalan para los miembros de los Tribunales Superiores de Justicia" (artículo $5^{\circ}$ ). Esto significó que se garantizaba que estas autoridades mantendrían su cargo mientras durara su buen comportamiento y que sólo podían ser destituidas a través de un procedimiento judicial iniciado a petición del presidente de la República. De esta manera, esta regulación debilitó el control del presidente sobre la Contraloría General, y fortaleció su independencia.

En suma, a pesar de la divergencia original con su contraparte norteamericana, hacia 1932 la Contraloría General de la República exhibía un grado razonable de independencia, aunque tenía fuertes lazos con el presidente de la República dado que el nombramiento del contralor era de su exclusiva responsabilidad. No obstante, el contralor tenía el poder de nombrar al resto de su personal sin influencias externas. Esta autoridad permanecería en el cargo mientras durara su

${ }^{63}$ Correa, Enrique, cit. (n. 14), pp. 157-161.

${ }^{64}$ Ibíd., p. 160

${ }^{65}$ En el Budget and Accounting Act of 1921, el contralor general ocuparía el cargo por 15 años, y no sería nombrado por un nuevo período. Además, este funcionario debía retirarse al alcanzar los 70 años de edad. Finalmente, se regulaba un procedimiento de remoción especial de acuerdo al cual el Congreso podría removerlo en caso de incapacidad o mal comportamiento (Véase la sección 303). 
buena conducta, y sólo podía ser destituido a través de un procedimiento judicial. Por lo tanto, como su contraparte norteamericana, este último régimen comenzó a reconocer la autoridad cuasi-judicial de la institución.

\section{La toma de razón}

La potestad más característica de la moderna Contraloría General es su poder para ejercer una revisión de legalidad ex-ante y obligatoria de los actos administrativos a través de la toma de razón. Además, en la toma de razón también puede tener lugar el poder del presidente de la República para insistir frente a una opinión negativa del contralor, es decir, frente a una representación. Aunque exhibe vestigios de regulaciones del siglo XIX, la forma moderna de este proceso de toma de razón se alcanzó predominantemente a través de una evolución progresiva durante los años que se analizan en este trabajo.

Ciertamente alguna forma de procedimiento de revisión ex-ante precede la creación de la Contraloría General de la República en $1927^{66}$. De hecho, tres de los principales cuerpos legales relativos al escrutinio financiero de la actuación administrativa en el siglo XIX contuvieron alguna versión de este mecanismo. Todas estas regulaciones otorgaban a los predecesores de la Contraloría General -la Contaduría Mayor y el Tribunal de Cuentas-poderes de autorización jurídica, aunque circunscritos a decretos de gasto y nombramiento ${ }^{67}$. Este dispositivo de verificación aparejaba la autoridad para impedir o representar la implementación de la decisión administrativa bajo control. El presidente de la República, a su vez, tenía el contra-poder de vencer este veto insistiendo en su decisión original. El órgano revisor tenía también el deber de reportar al Congreso en el caso de que el presidente ejerciera su poder de insistencia, para permitir que la asamblea legislativa lo hiciera políticamente responsable por potenciales infracciones al derecho. En contraste con el mecanismo moderno, sin embargo, las leyes que gobernaban el poder de insistencia en ese tiempo no requerían que el presidente de la República fuera respaldado por su gabinete ministerial completo para poder vencer el veto del órgano de control.

Hasta 1891 el poder de insistencia fue escasamente empleado, si es que alguna vez lo fue, probablemente debido a la inexistencia de controversias reales entre el presidente y los órganos de fiscalización ${ }^{68}$. Desde ese año en adelante, sin embargo, el Tribunal de Cuentas adoptó una aproximación activista, yendo más allá del control sobre los decretos de pago a través de una expansión de sus

${ }^{66}$ Silva Cimma, Enrique, Apuntes de derecho administrativo (Santiago, Editorial Universitaria, 1959), I, pp. 179-181.

${ }^{67} \mathrm{La}$ Ordenanza del Tribunal Superior de Cuentas y de la Contaduría Mayor de 1839 entregó una atribución comparable a la Contaduría Mayor (artículo 3 números 6 al 9). Nuevamente, una atribución similar fue otorgada al Tribunal de Cuentas en tanto sucesor de la Contaduría Mayor en la Ley sobre Organización de las Oficinas de Hacienda de 1875 en el artículo $3^{\circ}$ números 6 y 7. Por último, la ley de organización del Tribunal de Cuentas de 1888 contenía una atribución comparable en el artículo $5^{\circ}$ número 10 .

${ }^{68}$ Ceballos, Hildalgo, Estudio histórico y positivo de los decretos de insistencia (Santiago, Imprenta Roland, 1946), cap. 4. 
funciones examinadoras a todo tipo de decreto ${ }^{69}$. Esta actitud causó una serie de enfrentamientos constitucionales con los ministros y el Congreso dado que el tribunal fue acusado de estar invadiendo la esfera política ${ }^{70}$. Entonces, en 1920, el Congreso aprobó la ley $\mathrm{N}^{0} 3.620$, que reformó el Tribunal de Cuentas. La ley formalizó prácticas previas estableciendo que el tribunal debería controlar la legalidad de los decretos en general -no sólo los decretos de pago- y exigió la firma de todo el gabinete ministerial para poder dictar el decreto de insistencia ${ }^{71}$.

No es sorprendente que el DFL 400bis que creó la Contraloría General se haya apartado del sistema precedente, y haya intentado reforzar la naturaleza vinculante de la toma de razón respecto de las decisiones presidenciales. De hecho, reflejando la influencia de Kemmerer, este decreto no contempló el mecanismo de insistencia presidencial ${ }^{72}$. Dado que querían fortalecer los aspectos técnicos de las tareas de gobierno sobre los aspectos políticos, los asesores de la Misión Kemmerer se oponían a incluir una facultad de insistencia presidencial ${ }^{73}$. Así, esta regulación meramente estableció que todo pago requería autorización previa del contralor general, y que se debía considerar tanto la legalidad como la justificación del gasto (artículos 17 y 18). Pero la regulación no mencionaba la toma de razón, la representación, la insistencia, o el involucramiento del Congreso Nacional.

En octubre de 1927, no obstante, el renombrado profesor de derecho administrativo francés Gastón Jeze visitó Chile, y tuvo un impacto notable en la futura regulación de la toma de razón ${ }^{74}$. Su visión difería de la de Kemmerer en aspectos clave. Entre otras cosas, sugirió a los redactores que diseñaran la representación del contralor como un veto meramente relativo en vez de uno absoluto. Esto implicaba que el presidente podría vencer el veto del órgano de control en circunstancias excepcionales. Jeze argumentó que, siendo realista, un órgano técnico sería incapaz de obstruir el poder político del presidente. Dado que el veto absoluto podría terminar erosionando la credibilidad pública de la Contraloría General de la República, un veto relativo sería en los hechos una mejor herramienta para mantener las esferas técnicas y la política claramente separadas. Como es de esperar, estas sugerencias fueron bienvenidas por los funcionarios del ejecutivo, y fuertemente resistidas por los representantes de la Misión Kemmerer ${ }^{75}$.

Reflejando alguna de las visiones de Jeze, el DFL 2960bis retornó al modelo tradicional, pero con algunas variaciones destacables ${ }^{76}$. En primer lugar, el ámbito de la toma de razón fue ampliado, incluyendo no sólo los decretos de pago sino que todo decreto presidencial (artículo $8^{\circ}$ ). Por supuesto, esto es consistente con

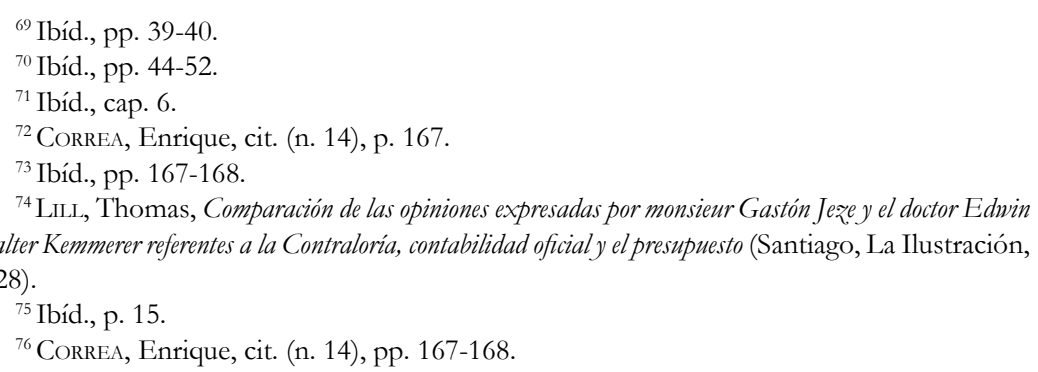


la solución a la que se había llegado en la ley N³ 3.620, de 1920. En segundo lugar, este decreto expresamente previó que la Contraloría General debía examinar la constitucionalidad y la legalidad de los decretos, como dos categorías distinguibles. En tercer lugar, a través de exigir que el presidente firmara el decreto de insistencia junto con todos sus ministros, el DFL 2960bis circunscribió su poder reactivo. En otras palabras, el Presidente tenía que mostrar públicamente que poseía suficiente respaldo político para superar el obstáculo jurídico impuesto por la Contraloría General de la República. Pero sería equivocado deducir de estas modificaciones que la intención fue aplacar los poderes del ejecutivo. De hecho, estos cambios fueron complementados por modificaciones que transformaban el poder de la Contraloría General en ilusorio. Para rechazar un decreto presidencial, la representación debía ser suscrita simultáneamente por el contralor y el subcontralor, ambos nombrados y removidos a discreción por el presidente de la República. Así, el poder de veto del órgano de control en los hechos era considerablemente débil. Además, el DFL 2960bis no incorporaba el involucramiento del Congreso Nacional en caso de que el presidente de la República dictara un decreto de insistencia. Sólo exigía que la oficina registrara el hecho en su Reporte Anual al Presidente.

El DL 258 de 1932 mantuvo las principales características de la regulación anterior. Aparentemente no incluyó cambios radicales (artículo $8^{\circ}$ ). Sin embargo, como ya se ha visto, este decreto había aumentado la independencia de la Contraloría General respecto de interferencias del Poder Ejecutivo de tal forma que el contexto institucional en el cual la toma de razón operaba era diferente y, en los hechos, reforzó su autoridad jurídica. Por entonces, la toma de razón consistía en un procedimiento conducido por una institución semi-independiente, que incluía todos los decretos, un escrutinio de constitucionalidad y legalidad, sometido a la insistencia presidencial, e involucrando deberes de reporte al Congreso en caso de insistencia.

En 1935, por primera vez, se inició un proceso de acusación constitucional en contra de ministros por el uso ilegal de poderes de insistencia ${ }^{77}$. Aunque la acusación constitucional no logró su propósito, ella revela la importancia de la toma de razón y especialmente de los decretos nonatos en ese tiempo, ya que este fue el principal motivo de la acusación. Los decretos nonatos fueron un mecanismo usado por el Poder Ejecutivo para blindar a los decretos de la toma de razón y así acelerar la acción administrativa. Consciente de una posible representación por parte del contralor, el respectivo ministro enviaba el decreto original junto con un decreto de insistencia. Así, se le ordenaba a la Contraloría General tomar razón del acto administrativo de inmediato sin mayor escrutinio. Más de 100 decretos nonatos fueron dictados entre 1933 y 1943, en tanto el contralor respaldó esta práctica ${ }^{78}$. Observadores en la época, sin embargo, criticaron este patrón de conducta calificándolo como una subversión del Estado de Derecho y del sistema

\footnotetext{
${ }^{77}$ Ceballos, Hidalgo, cit. (n. 68), pp. 78-83.

${ }^{78}$ Macías, Leopoldo, Los decretos de insistencia (Santiago, Talleres Gráficos Simiente, 1946), p. 55.
} 
de protección de la legalidad en que consistía la toma de razón ${ }^{79}$. En su opinión una operación correcta del mecanismo de toma de razón e insistencia requería la existencia de un genuino desacuerdo sobre la legalidad del decreto. Por lo tanto, el presidente no estaba autorizado a actuar con conciencia de la ilegalidad de su acción. Pronto, el contralor comenzó a rechazar los decretos nonatos y esta controvertida práctica terminó.

El ejemplo de los decretos nonatos revela la importancia que paulatinamente adquirió la toma de razón durante la década de 1930 y que se consolida a inicios de la siguiente década. Esto es ratificado por el relevante número decretos representados por la Contraloría General en este periodo. Si en 1933 la Contraloría General representaba sólo 2,5 por ciento de los decretos recibidos, a fines de la década promediaba el 4 por ciento. A esto se suma que los decretos de insistencia y los decretos nonatos no constituyeron una parte significativa de los decretos representados por la Contraloría General, como se aprecia en la tabla 1. Parece errado afirmar, por lo tanto, que "durante sus primeros veinte años, la Contraloría fue mayormente inefectiva, en tanto que raramente desafió la legalidad de decretos gubernamentales y, cuando lo hizo, sus decisiones fueron insistidas o ignoradas" $" 80$. En efecto, estas cifras sugieren la gradual transformación de la Contraloría General de la República de un asesor jurídico de facto a un supervisor independiente de la legalidad de la acción administrativa.

\begin{tabular}{|l|c|c|c|c|c|c|c|c|c|c|c|c|}
\cline { 2 - 13 } \multicolumn{1}{c|}{} & 1933 & 1934 & 1935 & 1936 & 1937 & 1938 & 1939 & 1940 & 1941 & 1942 & 1943 & 1944 \\
\hline Recibidos & 36.660 & 40.026 & 37.424 & 38.814 & 40.328 & 40.640 & 40.340 & 39.631 & 48.689 & 52.335 & 53.271 & 55.345 \\
\hline $\begin{array}{l}\text { Tomados } \\
\text { razón }\end{array}$ & 35.224 & 37.898 & 35560 & 37.253 & 38.337 & 38.689 & 37.454 & 37.898 & 46.217 & 50.442 & 50.413 & 52.082 \\
\hline $\begin{array}{l}\text { Represen- } \\
\text { tados }\end{array}$ & $\begin{array}{c}924 \\
(2,5 \%)\end{array}$ & $\begin{array}{c}1.569 \\
(3,9 \%)\end{array}$ & $\begin{array}{c}1.365 \\
(3,6 \%)\end{array}$ & $\begin{array}{c}1.287 \\
(3,3 \%)\end{array}$ & $\begin{array}{c}1.489 \\
(3,6 \%)\end{array}$ & $\begin{array}{c}1.469 \\
(3,6 \%)\end{array}$ & $\begin{array}{c}1.832 \\
(4,5 \%)\end{array}$ & $\begin{array}{c}1.715 \\
(4,3 \%)\end{array}$ & $\begin{array}{c}1.756 \\
(3,6 \%)\end{array}$ & $\begin{array}{c}1.953 \\
(3,7 \%)\end{array}$ & $\begin{array}{c}2.391 \\
(4,4 \%)\end{array}$ & $\begin{array}{c}3.263 \\
(5,8 \%)\end{array}$ \\
\hline Retirados & 512 & 559 & 499 & 274 & 502 & 482 & 1.054 & 818 & 716 & 750 & 467 & 334 \\
\hline $\begin{array}{l}\text { Decretos de } \\
\text { insistencia }\end{array}$ & 123 & 120 & 79 & 84 & 137 & 103 & 86 & 150 & 120 & 48 & 0 & 3 \\
\hline $\begin{array}{l}\text { Decretos } \\
\text { nonatos }\end{array}$ & 32 & 35 & 14 & 8 & 7 & 9 & 6 & 25 & 25 & 24 & 0 & 0 \\
\hline
\end{tabular}

TABla 1. La tOMA de Razón, 1933-1944 ${ }^{81}$

\section{La potestad dictaminante}

Finalmente, otra potestad distintiva de la Contraloría General de la República es su poder para emitir pronunciamientos vinculantes por los que interpreta la legislación aplicable al proceso administrativo. En contraste con las característi-

${ }^{79}$ Véase Ceballos, Hidalgo, cit. (n. 68), cap. 9; Macías, Leopoldo, cit. (n. 78), pp. 53-58; Silva Cimma, Enrique, Apuntes, cit. (n. 66), pp. 188-189; Aylwin, Patricio, Manual de derecho administrativo. Parte general (Santiago, Editorial Jurídica de Chile, 1952), pp. 185-186; Él MISMO, Derecho administrativo (Santiago, Editorial Universitaria, 1962), I, p. 65.

${ }^{80}$ Faúndez, Julio, Democratization, cit. (n. 6), p. 117.

${ }^{81}$ Elaboración propia con información obtenida de las Memorias Anuales DE LA ContraLORÍA GENERAl DE LA RepúBLiCA, complementada con Macías, Leopoldo, cit. (n. 78), pp. 54-54. 
cas ya analizadas, el origen de este poder no data de tiempos coloniales o de los planes de la Misión Kemmerer, sino que de reformas legales aprobadas en 1932 y complementadas posteriormente.

En la legislación del siglo XIX no hay un claro precursor de esta potestad. En la Ordenanza del Tribunal Superior de Cuentas y de la Contaduría Mayor de 1839, se encuentran una indicación de una potestad similar bajo la titularidad de la Contaduría Mayor. Se confiere a esta organización el poder de "Evacuar los informes que le pidan los Ministros de Estado i tribunales superiores de justicia" (artículo $3^{\circ}$ inc. 12). Pero el ámbito de esta potestad era considerablemente más estrecho que el contemporáneo. Ciertamente, ella no comprendía pronunciamientos acerca de la correcta interpretación de la legislación aplicable a los órganos de la administración del Estado. De hecho, el precepto ordenaba que la Contaduría Mayor consultara al presidente de la República en caso de dudas acerca de la "verdadera inteligencia que deba darse a las leyes, reglamentos, decretos $i$ cualesquiera otras disposiciones que tengan relación con los juicios de cuentas" (artículo $3^{\circ}$ inc. 17). Las interpretaciones que efectuara el presidente eran vinculantes para la Contaduría Mayor y no al revés - como es el caso con la norma moderna-.

Una potestad ligeramente comparable se encuentra en la Ley Orgánica del Tribunal de Cuentas de 1888. Esta regulación establecía que correspondía al Tribunal de Cuentas emitir los informes solicitados por el presidente dentro de su competencia (artículo $5^{\circ} \mathrm{N}^{\mathrm{o}} 13$ ). También le entregaba al tribunal para la facultad de solicitar al fiscal la emisión de dictámenes cuando fuera necesario (artículo $8^{\circ}$ $\mathrm{N}^{\mathrm{o}}$ 4). De hecho, una de las mentes jurídicas más destacadas de la época, el fiscal Valentín Letelier, forjó su reputación como figura clave del derecho administrativo chileno sobre la base de sus dictámenes al Tribunal de Cuentas ${ }^{82}$. Sin embargo, a pesar de su importancia histórica, esta potestad es difícilmente equivalente a la moderna y más amplia potestad dictaminante de la Contraloría General.

Tal como respecto de la toma de razón, el DFL 400bis no incluyó una potestad para emitir pronunciamientos jurídicos. El DFL 2960bis, sin embargo, sí reguló la materia en el artículo $7^{\circ}$, estableciendo que era uno de los deberes del contralor emitir informes escritos relativos a asuntos presupuestarios cuando fueran solicitados por jefes de servicio o funcionarios ${ }^{83}$. Así, este poder interpretativo estaba confinado a materias financieras y presupuestarias. No era una potestad de alcance general. Aunque estos informes eran vinculantes u obligatorios respecto de los funcionarios administrativos, ellos podían apelar en contra de ellos ante el presidente de la República por medio del ministro respectivo ${ }^{84}$. Este precepto, en consecuencia, nuevamente muestra los tonos presidencialistas del DFL 2960bis.

El DL 258 de 1932 fue el que finalmente incluyó la potestad dictaminante de la Contraloría General (artículo $7^{\circ}$ ). Pero esta regulación la expandió más allá de los asuntos financieros y presupuestarios, incorporando cuestiones relativas a la

\footnotetext{
${ }^{82}$ Véase LeTELIER, Valentín, Dictámenes de don Valentín Letelier: fiscal del Tribunal de Cuentas 1891-1918 (Santiago, La Ilustración, 1923).

${ }^{83}$ Hay una norma ligeramente similar en el Budget and Accounting Act of 1921, sección 312 b.

${ }^{84}$ CorreA, Enrique, cit. (n. 14), p. 167. Correa afirma que hacia 1930 esta potestad nunca había sido usada.
} 
"organización y funcionamiento de los servicios públicos" y "las atribuciones y poderes de los empleados públicos", entre otras materias. Este fue un paso crucial hacia la transformación de la organización en una institución predominantemente de control jurídico. Estos preceptos además reconocieron su potestad para interactuar con peticionarios públicos o privados para solicitar información o emitir órdenes. Asimismo, este cuerpo legal habilitó a la Contraloría para dictaminar respecto de asuntos relativos a la función pública, tales como salarios, pensiones, retiros, etc., "siempre que se susciten dudas para la correcta aplicación de las leyes respectivas". Así, la potestad para emitir interpretaciones jurídicas vinculantes sobre la legalidad administrativa comenzó a tomar contornos más precisos. Por último, a diferencia de la legislación anterior, el DL 258 de 1932 estableció que los informes del contralor no tendrían carácter meramente consultivo, sino que eran "obligatorios para funcionarios correspondientes, en el caso o casos concretos a que se refieran”. Además, es importante notar que la apelación ante el presidente de la República en caso de desacuerdo fue eliminada, aumentando nuevamente la separación entre la Contraloría General de la República y la Presidencia de la República.

Antes de concluir cabe hacer presente que sólo en 1952 aparecen todos los elementos contemporáneos de este poder interpretativo. Sólo con la ley N $\mathrm{N}^{\mathrm{0}} 10.336$ de 1952, los informes legales de la Contraloría General son llamados dictámenes y se reconoce que pueden ser emitidos "a petición de parte o de jefaturas de servicios $o$ de otras autoridades" (artículo $7^{\circ}$ ). De esa manera se admite que particulares y no sólo oficiales públicos puedan gatillar la emisión de estos informes. Luego, se concede una competencia exclusiva para "informar en derecho" sobre materias financieras y presupuestarias, asuntos relativos al Estatuto Administrativo y, en general, asuntos que tengan relación con "el funcionamiento de los servicios públicos que constituyen la Administración Civil del Estado para los efectos de la correcta aplicación de las leyes y reglamentos que los rigen" (artículo $8^{\circ}$ ). La expresión “informar en derecho" denota el carácter experto en asuntos legales que supone el ejercicio de esta competencia. Además, los asuntos sobre los cuales se puede pronunciar de forma exclusiva la oficina son la gran mayoría de materias que gobiernan la organización y el funcionamiento de la burocracia.

En esta ley de 1952 por primera vez se contiene una regla que delimita el ámbito de acción de la Contraloría General de la República respecto de otras instituciones, en particular el Consejo de Defensa del Estado. ${ }^{85} \mathrm{El}$ artículo $8^{\circ}$ inciso $2^{\circ}$ señala que no corresponde la intervención de la Contraloría respecto de asuntos que "por su naturaleza sean propiamente de carácter litigioso, o que estén sometidos al conocimiento de los Tribunales de Justicia”. La competencia respecto de estas materias

${ }^{85}$ En estricto rigor, esta regla se introdujo en el decreto supremo $\mathrm{N}^{\circ} 346$, de 13 de diciembre de 1928, que tuvo por propósito deslindar las competencias entre el Departamento Jurídico de la Contraloría y el Consejo de Defensa Fiscal. Enrique Correa explica que ese reglamento pretendía evitar que las reparticiones públicas se equivocaran respecto de a quién pedir un informe, en otras palabras, que "sus funciones estuvieran bien deslindadas". La misma regla, según Correa, buscaba que se fuera formando una "jurisprudencia administrativa”. Correa llega a afirmar que, ante la confusión y conflictos de atribuciones, el Consejo de Defensa Fiscal está de más. Véase CorreA, Enrique, cit. (n. 14), pp. 168-169. 
es del Consejo de Defensa del Estado, dice la nueva regulación. Pareciera que mientras el público de la Contraloría General son los órganos administrativos, los del Consejo son los tribunales. Esto pareciera fortalecer la posición institucional de la Contraloría vis-a-vis la burocracia, especialmente si se considera el corolario que la misma ley deduce de la norma anterior. Ella dice que "sólo las decisiones y dictámenes de la Contraloría General serán los medios que podrán hacerse valer como constitutivos de la jurisprudencia administrativa”. Así como la ley de 1932 amplió la distancia entre presidente de la República y la Contraloría General, esta ley pareciera haber ampliado la separación entre el funcionamiento del aparato judicial (en donde opera el Consejo de Defensa del Estado y los tribunales de justicia) y el aparato de control legal administrativo (en donde opera la Contraloría General y las distintas agencias administrativas que componen la administración pública).

Sin embargo, la importancia práctica de la potestad dictaminante ya era notoria a inicios de la década de 1940. En una obra de 1945, Enrique Silva Cimma destaca varios dictámenes de la Contraloría General dictados en esta época, relativos a una variedad de asuntos administrativos, tales como el empleo público en servicios fiscales (37.090, de 1940) y semifiscales (18.338, de 1944), a la juridicidad de contribuciones impuestas por la autoridad a empresas privadas (42.758, de 1941), al ingreso a Chile de extranjeros (22.466, de 1942), a la aplicación de franquicias a cooperativas agrícolas (31.047, de 1943), a las remuneraciones en el Poder Judicial (31.430, de 1943), entre otros ${ }^{86}$. Varios dictámenes se refieren a la operación de las municipalidades, en materia de urbanismo (4.248, de 1937), relación con los gobernadores (21.012, de 1939), otorgamiento de permisos y concesiones (36.257, de 1939), necesidad de contar con el acuerdo de los regidores para alterar contratos municipales (11.307, de 1941), y enajenación de bienes municipales (11.190, de 1943$)^{87}$. Como se puede apreciar, las materias sobre las que se pronunciaba la Contraloría General son diversas y se refieren a la operación de distintos tipos de órganos estatales. Además se debe destacar que ya en esa época los solicitantes iban desde servicios públicos y alcaldes hasta empleados públicos y empresas privadas.

La operación de este sistema exigió que la misma Contraloría General se adaptara internamente para asegurar la calidad de su razonamiento y la consistencia de sus decisiones. Así, por un lado, el Departamento Jurídico -que en opinión de Silva Cimma fue una "innovación posterior en nuestro sistema" que le dio a la Contraloría General "un carácter original y sui-generis" en el contexto internacional- implementó un sistema de trabajo basado en la discusión interna ${ }^{88}$. En 1929 incluso se creó el Consejo de Abogados de la Contraloría que discutía sobre consultas que trataran de materias especialmente importantes ${ }^{89}$. En el funcionamiento de este órgano, uno de los abogados relataba al Consejo el asunto, las dudas que hubieran surgido y la opinión que se hubiere formado, y luego, antes de tomarse un acuerdo, debía "debatirse suficientemente la cuestión”, votar en

${ }^{86}$ Silva Cimma, Enrique, La Contraloría General de la República (Santiago, Nascimento, 1945), pp. 233-263.

${ }^{87}$ Ibíd., pp. 263 ss.

${ }^{88}$ Ibíd., p. 81.

${ }^{89}$ Ibíd., pp. 124-127. 
orden inverso de antigüedad, y dejar constancia en un acta de la discusión "consignándose con total claridad y precisión, la totalidad de las opiniones emitidas por cada uno de los abogados" ". Sin embargo, ya en 1945, Silva Cimma se lamentaba que la operación de este consejo "ha ido cayendo con el tiempo en el desuso hasta el punto de afirmar que, actualmente, no se reúne nunca"91. Por otra parte, la Contraloría General desarrolló un mecanismo para asegurar la consistencia en su trabajo para lo que cual en 1943 se creó la Sección Relacionadora, cuya función fue evitar contradicciones en la jurisprudencia administrativa, es decir, "mantener la unidad de criterio que debe existir en los dictámenes emitidos"92. Otra tarea de esta oficina era "confeccionar sistemáticamente la historia de la ley [...] para facilitar la interpretación de leyes cuyos textos sean oscuros o dudosos"93. El surgimiento de este departamento interno revela la creciente necesidad de la Contraloría General de racionalizar su funcionamiento debido al aumento del número y complejidad de sus pronunciamientos jurídicos que interpretaban la legislación administrativa.

En conclusión, el origen de este poder interpretativo no está en la regulación del siglo XIX ni en las leyes que crearon a la Contraloría General de la República. Esta potestad aparece con sus rasgos actuales en 1932 y luego se consolida en la regulación de 1952, tras más de una década de operación práctica. En aquel tiempo la oficina ya había experimentado una transformación de entidad de control presidencial a una de control legal independiente.

\section{CONCLUSIÓN}

El objeto de este trabajo ha sido examinar el origen de la Contraloría General de la República entre el año de su establecimiento y el año 1943. Este último año marca un crucial hito de esta institución en el que se la introdujo en la Constitución, reforzando su estatus en el sistema constitucional chileno. En el período estudiado la Contraloría General lentamente comenzó a perfilar sus rasgos como el guardián de la legalidad administrativa que hoy conocemos. En un comienzo, sin embargo, esta institución operó en función de la enorme concentración de poder en el presidente de la República tras la dictación de la Constitución de 1925. En efecto, tanto en sus características como en su cultura institucionales, la Contraloría General tenía por propósito colaborar con el presidente de la República en la tarea de modernizar y profesionalizar una burocracia pública de comportamiento disfuncional en las últimas décadas.

Tras la revisión efectuada, tres características de la Contraloría General de la República destacan en este período. En primer lugar, el contexto constitucional influyó fuertemente en cómo ella fue concebida. Por un lado, ella fue un engranaje en la masiva reforma a la administración pública tras la dictación de la nueva Constitución. Por otro lado, la imperfecta concreción de los tribunales

\footnotetext{
${ }^{90}$ Resolución $\mathrm{N}^{\circ} 13$, de junio de 1930, del contralor general de la República.

${ }^{91}$ Silva Cimma, Enrique, La Contraloría, cit. (n. 86), p. 126.

${ }^{92}$ Ibíd., p. 218.

${ }^{93}$ Ibíd., p. 220.
} 
contencioso-administrativos en la Constitución de 1925 generaría un vacío institucional que sería suplido en las décadas posteriores por la Contraloría General en términos de interpretación jurídica. En segundo lugar, la Contraloría General fue fuertemente influida por el contexto político-cultural de su establecimiento. Por un lado, la influencia del programa de reformas de Kemmerer ubicó a la Contraloría General en un sendero tecnocrático y modernizador que se iría profundizando con el tiempo. Asimismo, Pablo Ramírez, su primer jefe superior, le imprimió una cultura tecnocrática que tendría un duradero impacto en la institución. Como consecuencia de la influencia directa e indirecta de este reconocido actor político, la Contraloría General fue progresivamente desarrollando una cultura burocrática e ingenieril que reaccionaba contra el dominio de los abogados y el legalismo en el sector público hasta ese entonces. Esto fue fruto de cambios en actitudes políticas que eran cada vez más proclives a la introducción de técnicas de gestión orientada a la eficacia y la eficiencia en el sector público. En tercer y último lugar, hacia el final del período estudiado la Contraloría General lentamente comenzó a gestarse como una entidad de control jurídico, independiente del Poder Ejecutivo. Características modernas de la Contraloría General como su autonomía, una robusta toma de razón y una potestad dictaminante con claros elementos jurídicos, no estaban presentes en 1927. Estas fueron apareciendo a través de una serie de reformas que casi azarosamente fueron convirtiendo a esta institución en un órgano de control jurídico y no meramente de control financiero y contable.

Las características anteriores, que han sido destacadas y analizadas en este trabajo, permitieron que a partir de la década de 1940 estuvieran instaladas varias de las condiciones necesarias para que la Contraloría General de la República se embarcara en una transformación aún más importante en las décadas siguientes. Con la reforma constitucional de 1943 y luego con la acusación constitucional contra el contralor Agustín Vigorena en 1945 la institución terminó de transformarse en el guardián de la legalidad administrativa.

\section{BiBLIOGRAFÍA}

Aylwin, Patricio, Manual de derecho administrativo. Parte general (Santiago, Editorial Jurídica de Chile, 1952).

—Derecho administrativo (Santiago, Editorial Universitaria, 1962), I.

BARRÍA, Diego, Rasgos burocráticos en las reformas administrativas en el Chile de la década de 1880, en Historia Crítica, 56 (2015), pp. 61-84.

—Positivism, Evolutionism, and Public Administration: The Work of Valentin Letelier (18861917), en Administrative Theory \& Praxis, 39 (2017), pp. 275-291.

-Carreras administrativas en Chile, 1884-1920 ¿Patronazgo o carreras burocráticas?, en Historia, 51 (2018), pp. 317-338.

- An Honourable Profession: Public Employees and Identity Construction in Chile, 1880-1920, en Bulletin of Latin American Research, 38 (2019), pp. 179-191.

Bernaschina, Mario, Manual de derecho constitucional (Santiago, Editorial Jurídica de Chile, 1951), II.

Bernedo, Patricio, La prosperidad económica bajo Carlos Ibáñez del Campo 1927-1929, en Historia, 24 (1985), pp. 5-105. 
BRAVO, Bernardino, Régimen de gobierno y partidos políticos en Chile 1924-1973 (Santiago, Editorial Jurídica de Chile, 1986).

Bronfman, Alan, Génesis de la delegación legislativa en el régimen constitucional de 1925, en Revista de Estudios Histórico-Jurídicos, 40 (2018), pp. 309-340.

Cane, Peter, Controlling Administrative Power: An Historical Comparison (Cambridge University Press, 2016).

Ceballos, Hildalgo, Estudio histórico y positivo de los decretos de insistencia (Santiago, Imprenta Roland, 1946).

Correa, Enrique, La Contraloría. El presupuesto del estado. Su control (Santiago, Talleres Gráficos San Rafael, 1928).

De Ramón, Armando, Miembros de los Poderes Ejecutivo, Legislativo y Judicial (Ediciones Universidad Católica de Chile, 2003), III.

Drake, Paul, The Money Doctor in the Andes: The Kemmerer Missions, 1923-1933 (Duke University Press, 1989).

Esponda, Jaime, Pablo Ramírez: el chileno desconocido (Santiago, Ril Editores, 2013).

Estévez, Carlos, Reformas que la Constitución de 1925 introdujo a la de 1833 (Santiago, Universidad de Chile, 1942).

FÁundez, Julio, Democratization, Development, and Legality: Chile, 1831-1973 (New York, Palgrave Macmillan, 2007).

-Chilean Constitutionalism before Allende: Legality without Courts, en Bulletin of Latin American Research, 29 (2010), pp. 34-50.

FigueroA, Virgilio, Diccionario histórico biográfico y bibliográfico de Chile (Santiago, Balcells \& Co., 1931), IV-V.

—Diccionario histórico biográfico y bibliográfico de Chile (Santiago, Balcells \& Co., 1931), III.

Góngora, Mario, Ensayo histórico sobre la noción de estado en Chile en los siglos XIX y XX

(Santiago, Editorial Universitaria, 1986).

Guerra, José Guillermo, La Constitución de 1925 (Santiago, Establecimientos Gráficos

Balcells \& Co., 1929).

Hilbink, Lisa, Judges Beyond Politics in Democracy and Dictatorship: Lessons from Chile (Cambridge University Press, 2007).

IbÁÑEz, Adolfo, Los ingenieros, el estado y la política en Chile. Del Ministerio de Fomento a la Corporación de Fomento 1927-1939, en Historia, 18 (1983), pp. 45-102.

Jocelyn-Holt, Alfredo, La Contraloría General de la República: Su sentido histórico, en Estudios Públicos, 137 (2015), pp. 133-149.

Junta de Gobierno (eds.), Los tribunales contenciosos administrativos. Antecedentes para su estudio (Valparaíso, Armada de Chile, 1982).

Letelier, Valentín, Dictámenes de don Valentín Letelier: fiscal del Tribunal de Cuentas 1891 1918 (Santiago, La Ilustración, 1923).

Lessig, Lawrence y Sunstein, Cass, The President and the Administration, en Columbia Law Review, 94 (1994), pp. 1-123.

LiLL, Thomas, Comparación de las opiniones expresadas por monsieur Gastón Jeze y el doctor Edwin Walter Kemmerer referentes a la Contraloría, contabilidad oficial y el presupuesto (Santiago, La Ilustración, 1928).

LóPEz, Elvira, Elproceso de formación de la burocracia estatal cbilena, 1810-1930, en RENGIFO, Francisca (ed.), Historia politica de Chile, 1810-2010 (Santiago, Fondo de Cultura Económica, 2017), II, pp. 55-85.

Macías, Leopoldo, Los decretos de insistencia (Santiago, Talleres Gráficos Simiente, 1946). 
Mashaw, Jerry, Creating the Administrative Constitution: The Lost One Hundred Years of American Administrative Law (Yale University Press, 2012).

Mosher, Frederick, The GAO: The Quest for Accountability in American Government (Westview Press, 1979).

Pantoja, Rolando, La jurisdicción contencioso-administrativa: decisiones legislativas al año 2001 (Santiago, Fundación Facultad de Derecho, 2001).

Pantoja, Rolando, La inexplicable ausencia de una justicia administrativa en el estado de Chile, en Revista de Derecho del Consejo de Defensa del Estado, 13 (2005), pp. 27-69.

Pinto, Sonia; Méndez, Luz María; Vergara, Sergio, Antecedentes históricos de la Contraloría General de la República (Santiago, Contraloría General de la República, 1977).

Silva Bascuñán, Alejandro, Tratado de derecho constitucional. La Constitución de 1925 (Santiago, Editorial Jurídica de Chile, 1963), III.

Silva Cimma, Enrique, La Contraloría General de la República (Santiago, Nascimento, 1945).

- Apuntes de derecho administrativo (Santiago, Editorial Universitaria, 1959), I.

-Derecho administrativo chileno y comparado. El servicio público (Santiago, Editorial Jurídica de Chile, 1995).

- Memorias privadas de un hombre público (Santiago, Editorial Andrés Bello, 2000).

Silva, Patricio, Pablo Ramirez: A Political Technocrat Avant-La-Lettre, en Centeno, Miguel y SiLvA, Patricio (eds.), The Politics of Expertise in Latin America (Macmillan, 1998), pp. 52-76.

-In the Name of Reason: Technocrats and Politics in Chile (Pennsylvania State University Press, 2008).

Trask, Roger, Defender of the Public Interest: The General Accounting Office, 1921-1966 (US General Accounting Office, 1996).

VILE, MJC, Constitutionalism and the Separation of Powers ( $2^{\mathrm{a}}$ ed., Liberty Fund, 1998).

YÁÑEz, Juan Carlos, Antecedentes y evolución histórica de la legislación social en Chile entre 1906 y 1924, en Revista de Estudios Histórico-Jurídicos, 21 (1999), pp. 203-210.

YÁÑ̃z, Juan Carlos, La intervención social en Chile, 1907-1932 (Santiago, Ril Editores, 2008). 